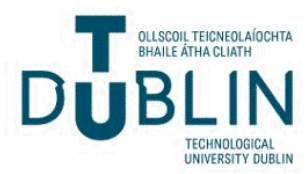

Technological University Dublin

ARROW@TU Dublin

Practitioner Research Projects

Learning Teaching \& Assessment Programme

Outputs

2018-11-01

\section{Problem-Based Learning as an Authentic Assessment Method}

\author{
Stuart Henderson \\ Technological University Dublin, stuart.henderson@tudublin.ie \\ Mary Kinahan \\ Technological University Dublin, mary.kinahan@tudublin.ie \\ Elaine Rossiter \\ Technological University Dublin, elaine.rossiter@tudublin.ie
}

Follow this and additional works at: https://arrow.tudublin.ie/ltcpgdprp

Part of the Higher Education and Teaching Commons, and the Scholarship of Teaching and Learning Commons

\section{Recommended Citation}

Henderson, S., Kinahan, M., Rossiter, E. (2018) Problem-based learning as an authentic assessment method. PG Diploma in Practitioner Research Projects, DIT, 2018.

This Report is brought to you for free and open access by the Learning Teaching \& Assessment Programme Outputs at ARROW@TU Dublin. It has been accepted for inclusion in Practitioner Research Projects by an authorized administrator of ARROW@TU Dublin. For more information, please contact arrow.admin@tudublin.ie, aisling.coyne@tudublin.ie,gerard.connolly@tudublin.ie.

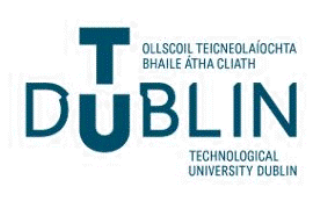




\title{
Problem-based learning as an authentic assessment method
}

\author{
Stuart Henderson, Mary Kinahan, Elaine Rossiter \\ Dublin Institute of Technology (www.dit.ie)
}

\section{Introduction}

Traditional learning and assessment typically focus on students being told what to do, memorising it, and the teacher assigning a problem on how to use it (Savery, 2006). By contrast, in problem-based learning (PBL) and assessment a problem is assigned to a group or individual, the teacher then facilitates the students' learning as they identify what they need to know, and the students learn and apply a solution to the problem (Savery, 2006). PBL was developed and pioneered by Barrows and Tamblyn in McMaster University as part of the Medical School programme due to students' lack of application of their learning and disengagement with traditional teaching methods. Although primarily used in STEMM education, PBL has been found to be very effective in other areas of education and continues to be widely used in higher education (Dolmans et al., 2005).

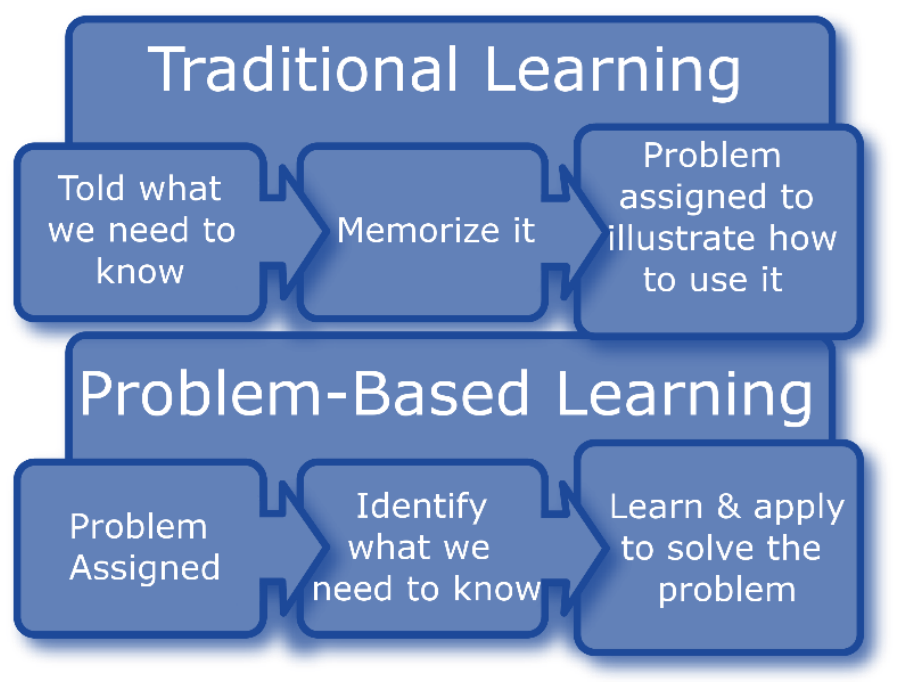

Figure 1: Traditional learning vs. problem-based learning (Southern Illinois University Edwardsville, n.d.)

Given the evidence that PBL is an effective approach to learning, the main aim of our project is to examine PBL as an alternative and more authentic assessment than the current examdriven approach in a business school context. In this project, we examined three questions: (1) Is PBL an authentic assessment and alternative to the exam approach? (2) Does PBL help students in the development of DIT graduate attributes and research skills? (3) Is PBL useable and useful in the business school context? In analysing these three questions, we provide evidence based on the literature that PBL is an effective and authentic alternative to exam assessments and is adaptable to the business school context.

In today's ever changing and fast paced world, it is important that we have a learning approach and assessment that reflects the complexity of this new context (Awang \& Ramly, 
2008). Whilst exam-driven approaches focus on learning content, modern and novel approaches like PBL focus on both process and content. In doing so, students develop a more whole holistic approach to the topic that incorporates teamwork, originality and understanding. Similarly, in recent years, employers' desired graduate attributes have shifted from specific to broader transferable skills such as communication skills, critical thinking, research skills etc. However, according to the World Economic Forum (2015), Ireland had lower percentages of critical thinking and creativity compared to other OECD countries. Thus, it is essential to develop a learning strategy that includes authentic assessment that is suitable and can adapt to the changing world of learning and work.

\section{Theoretical Background}

PBL is a student-centred pedagogy that is defined as "the learning that results from the process of working towards the understanding of a resolution of a problem. The problem is encountered first in the learning process" (Barrows \& Tamblyn, 1980, p. 1). Based on the constructivist approach, PBL encourages students to engage in self-directed problem solving and teamwork in a manner that develops their knowledge of the topic through active learning which results in better knowledge retention, understanding, and helps in the development of transferable and life skills (Barrett \& Cashmen, 2010; Wood, 2003). PBL focuses on students' learning through the experience of solving open-ended problems, however unlike contentdriven approaches, PBL focuses on both content and process. For example, an important aspect of PBL is to share understanding in a group to allow students to reflect on their own and others' reasoning and in turn their own learning process (Kemp, 2011).

Building on the constructivist approach, PBL is based on Seven Instructional Principles that focuses on learners conducting research, integrating theory and practice, and applying knowledge and skills to develop appropriate solutions to a problem anchored in real-world context (Lebow, 1993). The instructional principles for PBL deriving from constructivism are as follows (Savery \& Duffy, 1995, p. 3-7):

1. Anchor all learning activities to a larger task or problem, that is, there is a reason or purpose to the assignment that makes sense to the learner.

2. Support the learner in developing ownership for the overall problem or task, that is, focus on the goals of the learner alongside the learning objectives to shift learners from focusing on 'passing the test' to actively engaging and owning the task.

3. Design an authentic task, that is, the learner should be engaged in problem-solving that is consistent with the cognitive demands of their future workplace or career (Honebein, Duffy, \& Fishman, 1993)

4. Design the task and the learning environment to reflect the complexity of the environment they should be able to function in at the end of learning.

5. Give the learner ownership of the process used to develop a solution, in that, the teacher must act as a facilitator not instructor, allowing the learner ownership of not just the problem itself, but also the process of problem solving. For example, presenting the problem alongside learning objectives and assigned readings would be counterproductive if the teacher is trying to engage students in an authentic assessment and ownership. In PBL, the process of solving the problem is as important, or even more important, than the solution.

6. Design the learning environment to support and challenge the learner's thinking, that is, the teacher must be a consultant and coach, provoking and challenging the learner's thinking through posing questions, without taking ownership from the learner using the 'learning scaffold approach' to bring students up to their 'zone of proximal development' (Vygotsky, 1978). 
7. Encourage testing ideas against alternative views and contexts, that is, this focuses on knowledge being socially negotiated through discussing issues with others and understanding of others' perspectives of these issues. In doing so, this enriches the learning environment for the learner and broadens their understanding. Thus collaborative learning groups is a central premise to the PBL approach (Savery \& Duffy, 1995, p. 3-7).

In addition to the Seven Principles, an eighth principle was added focusing on the importance of reflection on both the content and the process of learning (Savery \& Duffy, 1995). Incorporating these principles, PBL is a total student-centred pedagogical approach to learning that focuses on understanding the problem raised through self-directed learning skills, then through discussion and collaboration within a team (Major \& Palmer, 2001). PBL, unlike more traditional approaches, also restructures the teacher-learner dynamic, where the teacher moves from instructor to facilitator allowing learners more ownership (Mergandoller, Maxwell, \& Bellismo, 2006). Although PBL can be adapted to be included as just a type of assessment in a traditional module, PBL is most effective as a complete holistic approach to curriculum design and implementation. However, such an approach provides its own advantages and disadvantages (Awang \& Ramly, 2008).

\section{Advantages and Disadvantages of PBL}

From its origins in the medical field, PBL has shown a flexibility which has allowed it to be adapted and tailored to different educational contexts ranging from engineering to business (Awang \& Ramly, 2008). PBL is considered an engaging and strong learning strategy that results in better transfer of learning, development of transferable skills such as critical thinking, and sustained learning (Mergandoller et al., 2006). PBL has many benefits (e.g., promotes real world problem solving, student-centred etc.), but also has serious disadvantages (e.g., time and resource consuming, viability issues, etc.) (Savery, 2006) (Table $1)$.

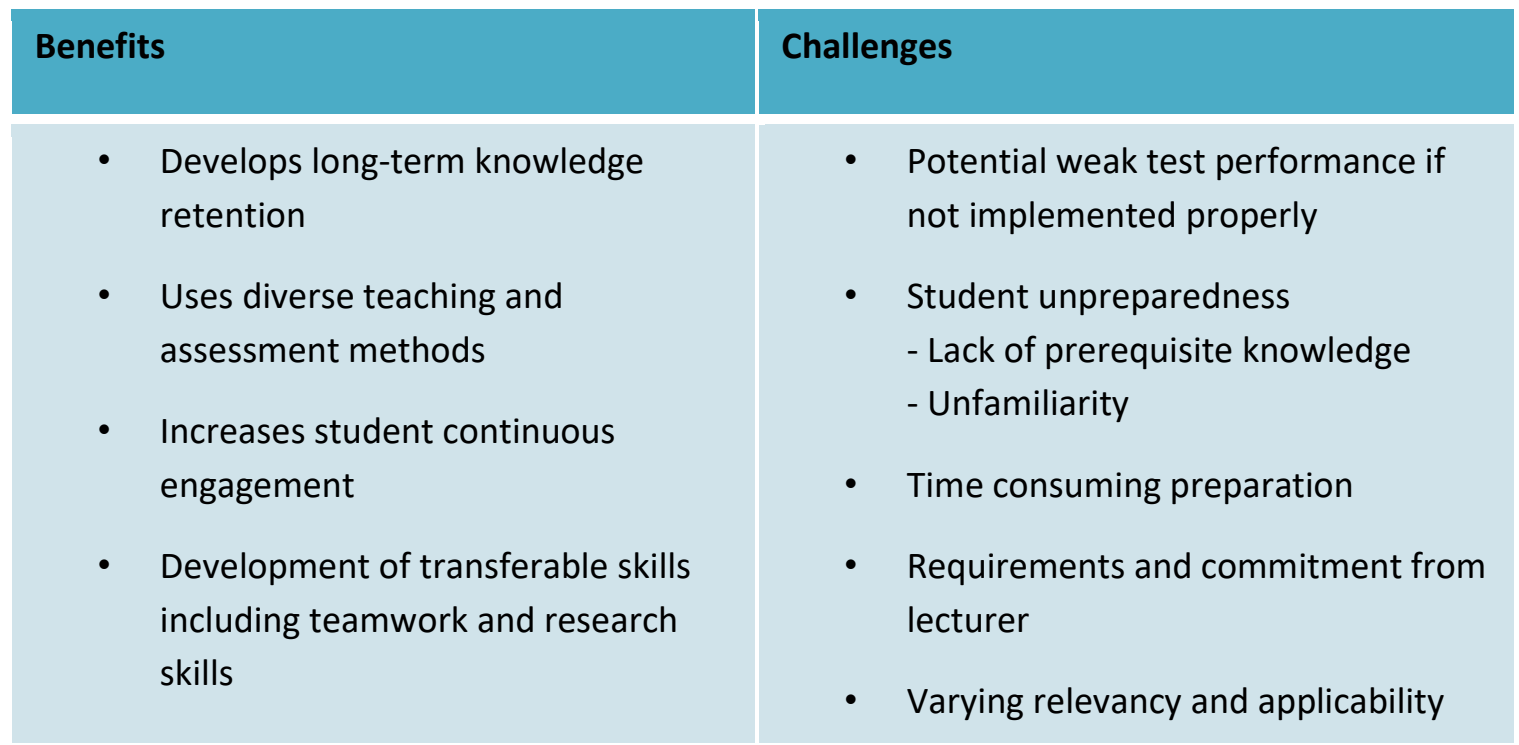

Table 1: Benefits and Challenges of PBL (Awang \& Ramly, 2008; Ribeiro, 2011)

One of the main benefits of PBL is its perceived effectiveness in increasing long-term knowledge retention and development of transferable skills (Belland, et al., 2006; Mergandoller et al., 2006). However, in meta-analyses, results have been mixed on whether 
PBL is actually an effective learning strategy (Newman, 2003; Sanson-Fisher \& Lynagh, 2005). There has been some criticism of meta-analyses or systematic reviews of PBL, due to the lack of inclusion of well-designed PBL higher education programmes (Brush \& Saye, 2008; Savery, 2006). Thus, arguably to reap the positive effects of PBL, PBL must be at the heart of a constructively-aligned module with consistent and proper design, implementation, and delivery (Savery, 2006). In particular, even if PBL is introduced as only a type of authentic assessment, several other issues need to be examined in terms of curriculum and module design and implementation for PBL to be effective due to the marrying of theoretical and practical/applied problem-solving (Awang \& Ramly, 2008). Thus, for PBL to be effective, there needs to be a large investment of time and effort on the part of the teacher/lecturer and investment of resources by the school/college, which can be problematic for staff and schools. Despite lack of evidence on its effectiveness, and the involvement of a lot of preparation and time, PBL has been widely acknowledged as having a more beneficial effect for learners than traditional methods, especially for non-academic learners (Biggs, 1999; Biggs \& Tang, 2011).

\section{PBL as an Authentic Assessment}

Despite mixed opinions on the effectiveness of the PBL approach, it is clear that PBL is an authentic assessment. An authentic assessment is defined as an assessment that "has meaning or value beyond success in school" (Newman, Brandt \& Wiggins, 1998, p. 19). According to Brady and Kennedy (2012), authentic assessments have many advantages such as providing real-life learning, student-centricity, and being embedded in real-world contexts. PBL encourages development of trust, motivation, creativity and growth in learning and consequently allows for an authentic learning environment in which students can learn in an authentic manner (Barber, King, \& Buchanen, 2015; Eisner 1998). As both PBL and authentic assessment are based on constructivism they have many things in common, and constructively align from learning to assessment. For example, Barber, King, and Buchanen, (2015) map the clear overlap of authentic assessments and PBL (Table 2).

\begin{tabular}{|l|l|}
\hline Problem-based learning & Authentic assessment \\
\hline - Real world situations & - Real world tasks \\
\hline Collaborative work & - Collaborative assessment \\
- Co-constructed solutions & - Co-constructed assessments \\
- Multiple outcomes & - Multiple products and artefacts
\end{tabular}

Table 2: Comparison of PBL and Authentic Assessment (Barber, King, \& Buchanen, 2015) 


\section{Application Process of PBL}

As with any instructional model, there are many strategies for implementing PBL. As illustrated by Barrett and Cashman's (2010) seven step process of PBL, the application of PBL is a step-by-step process that can be adapted for any context such as a business school. In our own areas of business (HRM and Economics), PBL has been used as an authentic assessment successfully (e.g. Ulster University, Forsythe, 2001). However as mentioned previously it is important to constructively align your approach so PBL is followed by a compatible authentic assessment.

\section{Step PBL Process Guide}

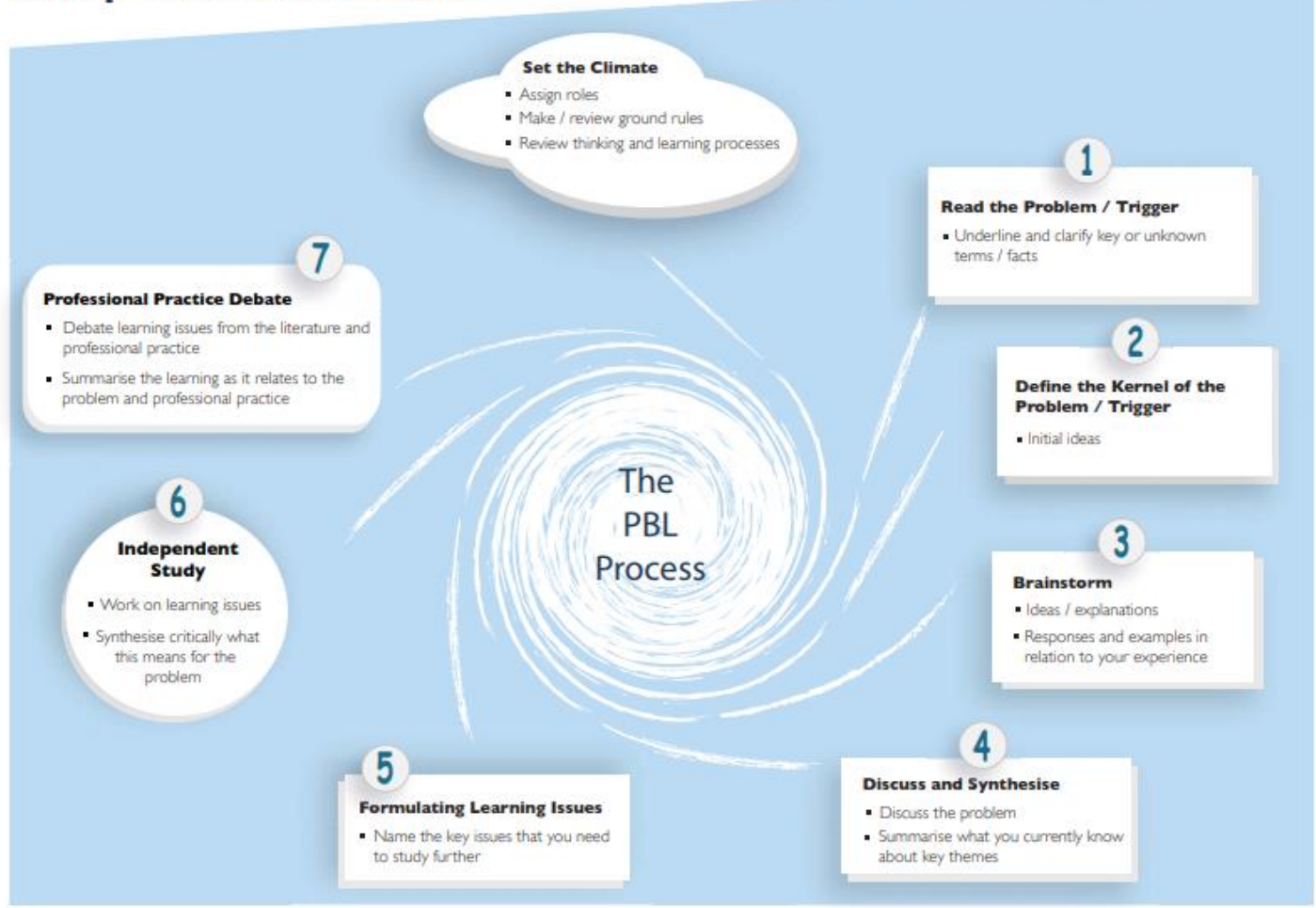

Figure 2: Seven step PBL process guide (Barrett \& Cashman, 2010)

Barrett and Cashman (2010, p. 9) outline a contemporary adaptation of the PBL process in seven steps, excluding the pre-step that involves 'setting the climate'

- Step 1: Read the problem/trigger

- Step 2: Define the kernel of the problem/trigger

- Step 3: Brainstorm

- Step 4: Discuss and synthesise

- Step 5: Formulating learning issues

- Step 6: Independent study

- Step 7: Professional practice debate

There are various different steps and processes, however central to PBL is that it is a student centric approach which allows self-directed learning by the student, and collaboration with others to increase understanding to 'solve a problem' set in the real world. 


\section{Conclusion and Recommendations}

The purpose of our report was to put forward the argument to use PBL as a student-centred and constructivist methodology leading to deeper learning and including authentic assessment. The arguments were strengthened and supported by engaging with relevant literature and from our own practical experiences. Overall, our research indicates that PBL reports positive outcomes related to student learning in the areas of content knowledge and the development of skills such as collaboration, critical thinking, and problem solving (Mergendoller et al., 2006). Our research also shows that PBL benefits students by increasing their motivation and engagement (Belland et al., 2006). A key element to the successful implementation of PBL is that the 'problem/project' is central and not peripheral to the curriculum. The 'problem' must focus on questions or issues that drive students to encounter the central concepts and principles of their specific discipline; it must be student-driven to a significant degree; problems need to be 'real world projects'; PBL must involve students in a constructive investigation and finally collaboration is crucial (Thomas, 2000).

We also recognise that several studies (Brush \& Saye, 2008) found that PBL is challenging to enact despite its positive benefits. Specifically, it requires a lot of effort at the inception and is challenging for lecturers to implement as it is very time-consuming, can feel disorderly and lecturers can feel that classrooms are difficult to control. Also, it can be hard for lecturers to balance between giving students independence and providing support and designing an authentic assessment can be challenging. Thus, we recommend both lecturers and students receive support. Lecturers need resources and support in order to design, implement and properly assess PBL for it to be effective. Students need support including help setting up and directing initial inquiry, organising their time to complete tasks, and understanding the process. We also recommend further research into integrating PBL with community-based learning as this might help with the design of authentic assessments as well as other positives associated with community-based learning. In summary, our research indicates that PBL has a positive effect on students but is challenging for lecturers to implement. However, with the correct support the benefits outweigh the challenges. We hope that this report has provided fellow lecturers with the proper knowledge for implementing PBL, as well as the motivation and drive to integrate this forward-thinking approach into their curriculum. 
Awang, H., \& Ramley, I. (2008). Creative Thinking Skill Approach through Problem-Based Learning: Pedagogy and Practice in the Engineering Classroom. World Academy of Science, Engineering and Technology, 16, 635-640.

Barber, W., King, S., \& Buchanan, S. (2015). Problem Based Learning and Authentic Assessment in Digital Pedagogy: Embracing the Role of Collaborative Communities. The Electronic Journal of e-Learning, 13(2), 59-67.

Barrett, T. \& Cashman, D. (Eds) (2010) A Practitioners' Guide to Enquiry and Problem-based Learning. Dublin: UCD Teaching and Learning.

Barrows, H. S., \& Tamblyn, R. M. (1980). Problem-Based Learning: An Approach to Medication Education. New York: Springer.

Belland, B. R., Ertmer, P. A., \& Simons, K. D. (2006). Perceptions of the Value of ProblemBased Learning among Students with Special Needs and Their Teachers. The Interdisciplinary Journal of Problem-based Learning, 1(2), 1-18.

Biggs, J. (1999). What the Student Does: teaching for enhanced learning. Higher Education Research \& Development, 18(1), 57-75.

Biggs, J., \& Tang, C. (2011). Teaching for Quality Learning at University: What the Student Does, 4th Edition. Buckingham: SHRE and Open University Press.

Brady, L. \& Kennedy, K. (2012). Assessment and Reporting: Celebrating Student Achievement. Australia: Pearson.

Brush, T., \& Saye, J. (2008). The Effects of Multimedia-Supported Problem-Based Inquiry on Student Engagement, Empathy, and Assumptions about History. The Interdisciplinary Journal of Problem-based Learning, 2(1), 21-56.

Dolmans, D. H. J. M., De Grave, W., Ineke, H. A., Wolfhagen, P., \& van der Vleuten, C. P. M. (2005). Problem-based Learning: Future Challenges for Educational Practice and Research. Medical Education, 39, 732-741.

Eisner, E. (1998). The Enlightened Eye: Qualitative Inquiry and the Enhancement of Educational Practice. Upper Saddle River, NJ: Prentice Hall.

Honebein, P., Duffy, T.M., \& Fishman, B. (1993). Constructivism and the Design of Learning Environments: Context and Authentic Activities for Learning. In Thomas M. Duffy, Joost Lowyck, and David Jonassen (Eds.), Designing Environments for Constructivist Learning. Heidelberg: Springer-Verlag.

Kemp, J. (2011). Constructivism and Problem-Based Learning. Learning Academy, 45-51.

Lebow, D. (1993). Constructivist Values for Systems Design: Five Principles Toward a New Mindset. Educational Technology Research and Development, 41, 4-16.

Major, C. \& Palmer, B. (2001). Assessing the Effectiveness of Problem Based Learning in Higher Education: Lesson from the Literature. Academic Exchange Quarterly, 5(1), 4-9.

Mergendoller, J. R., Maxwell, N. L., \& Bellisimo, Y. (2006). The Effectiveness of ProblemBased Instruction: A Comparative Study of Instructional Methods and Student Characteristics. The Interdisciplinary Journal of Problem-Based Learing, 1(2), 49-69.

Newman, M. (2003). A Pilot Systematic Review and Meta-Analysis on the Effectiveness of Problem-Based Learning. Retrieved from http://www.Itsn01.ac.uk/docs/pbl report.pdf

Newmann, F., Brandt, R. \& Wiggins, G. (1998). An Exchange of Views on Semantics, Psychometrics, and Assessment Reform: A Close Look at 'Authentic' Assessments. Educational Researcher, 27(6), 19-22. 
Ribeiro, Luis Roberto C. (2011). The Pros and Cons of Problem-Based Learning from the Teacher's Standpoint. Journal of University Teaching \& Learning Practice, 8(1), 2011.

Sanson-Fisher R. W., \& Lynagh, M., C. (2005). Problem-Based Learning: A Dissemination Success Story? Medical Journal of Australia, 183(5), 258-260.

Savery, J. R. (2006). Overview of Problem-based Learning: Definitions and Distinctions. The Interdisciplinary Journal of Problem-based Learning, 1, 9-20.

Savery, J. R. \& Duffy, T. R. (1995). Problem Based Learning: An Instructional Model and Its Constructivist Framework. Educational Technology, 35, 31-38.

Southern Illinois University Edwardsville, n.d. What is Problem-Based Learning (PBL)? Center for Faculty Development and Innovation. Retrieved from http://www.siue.edu/facultycenter/services resources/teaching/pbl.shtml

Thomas, J. W. (2000). A Review of Research on Project-Based Learning. Report Prepared for The Autodesk Foundation. Retrieved from http://www.bie.org/index.php/site/RE/pbl research/29

Vygotsky, L. (1978). Problems of Method (pp. 52-75). In Mind in Society. (Trans. M. Cole). Cambridge, MA: Harvard University Press.

Wiggins, G. (1990). Authentic Assessment. Practical Assessment, Research \& Evaluation, 2(2), 1-3.

Wood, D. (2003). ABC of Learning and Teaching in Medicine. British Medical Journals, 326, 328-330.

World Economic Forum (prepared in collaboration with The Boston Consulting Group). (2015). New Vision for Education Unlocking the Potential of Technology. Geneva: World Economic Forum. Retrieved from http://www3.weforum.org/docs/WEFUSA NewVisionforEducation Report2015.pdf 


\section{Problem Based Learning (PBL)}

\section{the journey}

Stuart Henderson, Mary Kinahan \& Elaine Rossiter

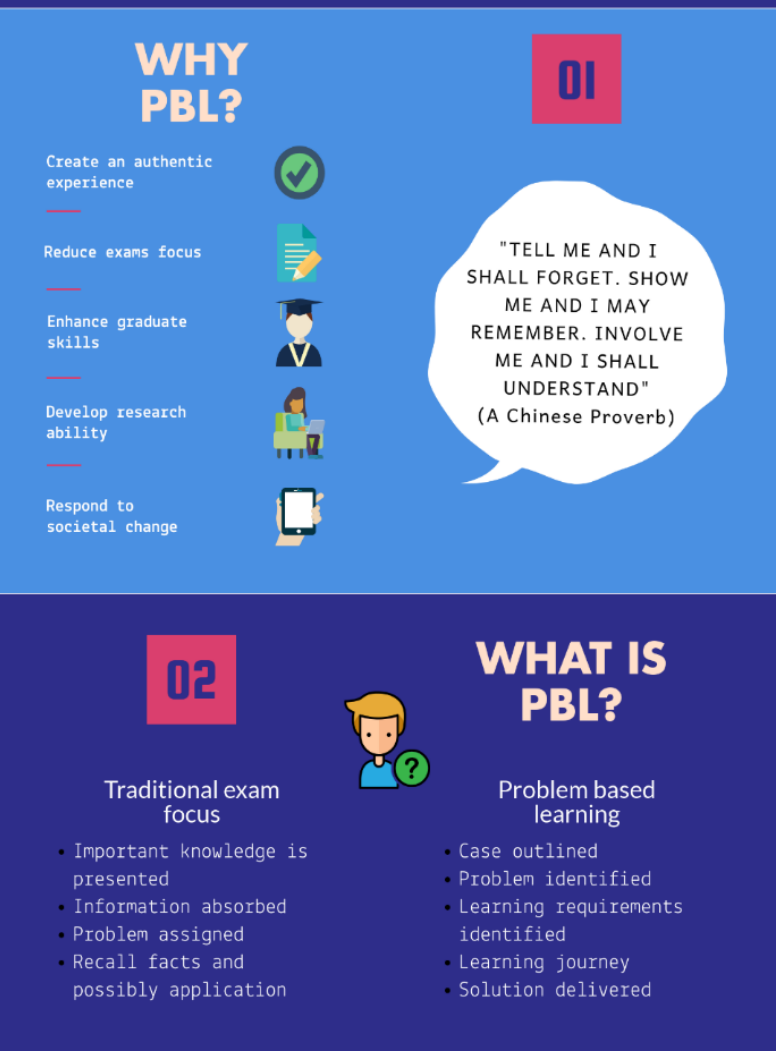

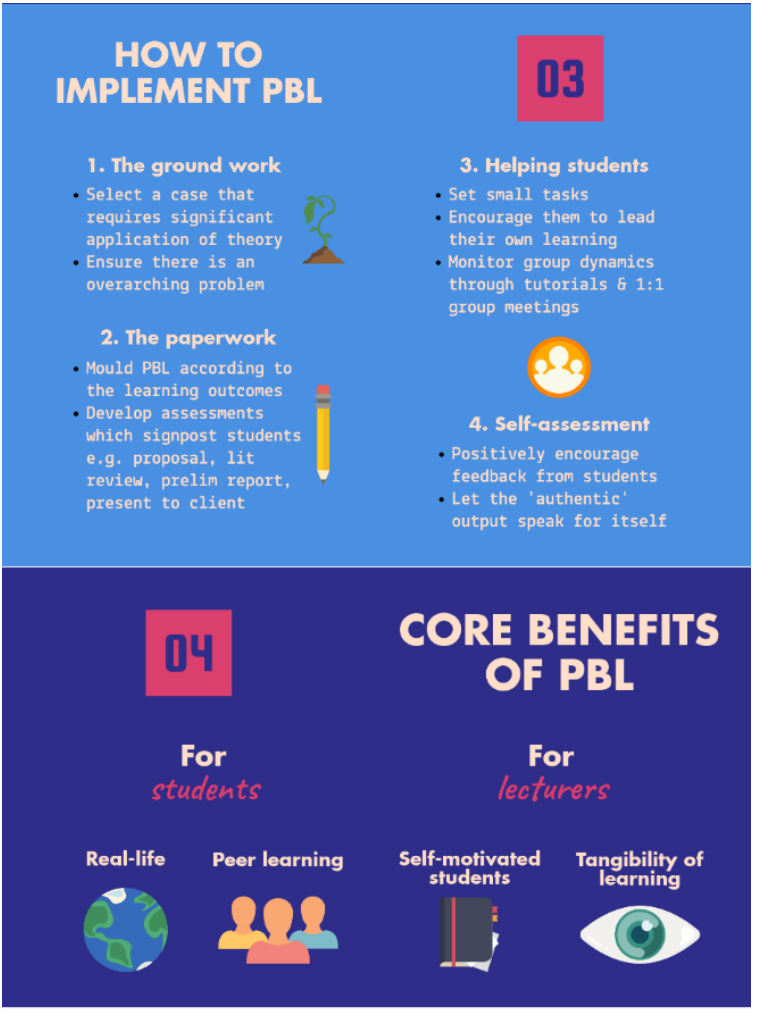

P PIKTOCHART 